\title{
Thoughts on Acupuncture Standardization Research Work outside the Mainland China
}

\author{
Fu-Ming Yang*, Yi Guo \\ Tianjin University of Traditional Chinese Medicine, Tianjin, China
}

Submission: February 24, 2018; Published: March 28, 2018

*Corresponding author: Fu-Ming Yang, Tianjin University of Traditional Chinese Medicine, Tianjin, China, Email: fumingyang1990@163.com

\section{Opinion}

As an important part of the Chinese medicine, acupuncture has been widely accepted throughout the world. WHO traditional medicine strategy 2014-2023 [1] pointed out: "according to the result of a survey conducted by the World Federation of Acupuncture and Moxibustion Societies, acupuncture was used in 183 out of 202 surveyed countries". As acupuncture has been promoted, the contribution of acupuncture standards cannot be ignored in the aspects of safety and quality, notably assessment of products and services, qualification of practitioners, methodology and criteria for evaluating efficacy. Standards sometimes work as region's management of certain industry. Management styles vary from country to country according to culture and policy etc. It is impossible to popularize universal standard system. Therefore, the establishment of regional standard system which fits the need of local people is particularly important.

Acupuncture law work as standards to regulate acupuncture industry in quite a few countries such as America, while previous researches have suggested that the study of acupuncture legislation should beyond the work of standardization. Acupuncture legalization is the prerequisite for standardization, Legislation is the embodiment of legalization. According to "a law on TM/CAM was defined as the first stage of legislative procedure. It is the rule of conduct imposed by the authority... may cover various areas in the TM/CAM field, including education of professionals, licensing of practitioners and manufacturers, manufacture of products used in TM/CAM, sales practices, etc." expressed by National policy on traditional medicine and regulation of herbal medicines 2 , acupuncture legislations should be regarded as part of standards of acupuncture.

As a part of Traditional Chinese Medicine (TCM) people use acupuncture for three general reasons:

i. As one of the primary sources of health care.

ii. Due to cultural and historical influences. iii. As complementary therapy [2]. Asian countries such as Japan and South Korea, which have a long history of cultural and historical exchanges with Chinese mainland, are still affected by culture and history. Most of the Western countries such as the United States tend to acupuncture as adjuvant therapy that is recognized as an effective complementary replacement therapy [3]. In our previous study [4] we found that technical standards and basic standards amount to the most part in Asian countries, while in western countries, management standards occupy the largest proportion of acupuncture standard systems. Possible reasons are as follows. Countries which have geographical proximity and cultural origins to China have favored formulating basic disciplines such as basic theory, scientific research, terminology, technique of acupuncture, while western countries, which use acupuncture as a complementary therapy tend to guide the lawful practitioners directly. The former formulate basic-oriented standard system while the later manage-oriented standard system.

Out of China several countries have already made some achievements in the standardization of acupuncture, Asian countries such as Japan and South Korea, western countries such as the United States and Australia. Standardization works in regions above can be used for reference by others.

\section{References}

1. WHO (2013) WHO Traditional Medicine Strategy: 2014-2023. World Health Organization, Geneva, Switzerland.

2. WHO (2005) National policy on traditional medicine and regulation of herbal medicines: report of a WHO global survey.

3. Jiao HG (2013) Research on Focuses and Cooperating Teams of International Acupuncture based on SCIE. China Academy of Chinese Medical Sciences.

4. Yang FM Yang Y, Daisuke W, Kim KW, Guo Y, et al. (2017) A Summary of standardization of acupuncture in Australia, Korea, Japan and America. World Journal of Acupuncture-Moxibustion 27(04): 20-26. 
This work is licensed under Creative

Commons Attribution 4.0 License

DOI: 10.19080/JCMAH.2018.05.555674

\section{Your next submission with Juniper Publishers will reach you the below assets}

- Quality Editorial service

- Swift Peer Review

- Reprints availability

- E-prints Service

- Manuscript Podcast for convenient understanding

- Global attainment for your research

- Manuscript accessibility in different formats

( Pdf, E-pub, Full Text, Audio)

- Unceasing customer service

Track the below URL for one-step submission https://juniperpublishers.com/online-submission.php 